\title{
Microplastic ingestion: Are seabirds more affected than other marine species?
}

\section{Ingestión de microplásticos: ¿Son las aves marinas más afectadas que otras especies marinas?}

\author{
Khrista Baran ${ }^{1}$, Casilda Saavedra ${ }^{2 *}$ \\ ${ }^{1}$ Wilkes University, ${ }^{2}$ Universidad Technológica de Panamá
}

\begin{abstract}
In recent times, plastic production has increased due to the convenience and multipurpose use. As plastic may make life easier on humans, the amount of plastic debris has increased as well as the effect on marine life. Since it is a relatively new topic, the effects on marine species are trying to be modeled in laboratories and observed in the field. The effects of plastic marine debris include but are not limited to entanglement, ingestion, possible bioaccumulation, chemical exposures, and even death. Larger plastics can become smaller particles, microplastics, which are difficult to study the effects on marine life due to the small size. Microplastics are a global issue that effect species. Some of the factors that are considered of why different organisms ingest plastics include: method of feeding, color, age, and accidental/secondary ingestion. The focus of this research article is the ingestion of average percentage of microplastics of seabird species compared to other marine species throughout the world.
\end{abstract}

Keywords Microplastic, ingestion, seabirds, effects.

Resumen En los últimos tiempos, la producción de plástico ha aumentado debido a la conveniencia y al uso multipropósito. Como el plástico puede hacer la vida más fácil a los seres humanos, la cantidad de desechos plásticos ha incrementado, lo mismo que los efectos en la vida marina. Dado que es un tema relativamente nuevo, los efectos de los microplásticos sobre las especies marinas están intentando ser modelados en laboratorios y observados en el campo. Los efectos de los desechos plásticos en las especies marinas incluyen, entre otros, el enredo, la ingestión, la posible bioacumulación, las exposiciones químicas e incluso la muerte. Los plásticos más grandes pueden convertirse en partículas más pequeñas, conocidas como microplásticos, que, debido a su reducido tamaño, hacen difícil el estudio de sus efectos en la vida marina. Los microplásticos son un problema global que afecta a las especies. Algunos de los factores que influyen en la afectación de especies marinas por microplásticos son: la alimentación, el color, la edad y la ingestión accidental / secundaria. El enfoque de este artículo de investigación es la ingesta del porcentaje promedio de microplásticos por especies de aves marinas en comparación con otras especies marinas en todo el mundo.

Palabras clave Microplástico, ingesta, aves marinas. Efectos.

* Corresponding Author: casilda.saavedra@utp.ac.pa

\section{Introduction}

Anthropogenic production has an effect on the environment. Specifically, plastic production has effects on marine organisms when it disposed of and becomes debris. The multiple, often single use, cheap, and durable material of plastic is having negative impacts on the world all for convenience[1]. Out of all forms of marine debris, $84 \%$ of species are affected by plastic while only $16 \%$ are affected by other forms of debris [2]. Plastic is easily dispersed across the oceans due to the ability to float, hard to break down properties, prevailing winds, and surface currents [3]. From 1572 different sampling sites, a model was created to estimate that there are about 5.25 trillion plastic particles that weigh about 268,940 tons[3].

Plastics can be divided into four different categories based on size: small microplastic $0.33 \mathrm{~mm}$ to $1.00 \mathrm{~mm}$, large microplastic $1.01 \mathrm{~mm}$ to $4.75 \mathrm{~mm}$, mesoplastic $4.76 \mathrm{~mm}$ to 200 $\mathrm{mm}$, and macroplastic greater than $200 \mathrm{~mm}$ [3]. Lusher mentions plastic production is a newer practice and increases annually by $5 \%$. Larger plastics are broken down creating microplastics. The hazards associated with the microplastic 
particles in marine life is not well known, but can create harmful effects [4]. There are some laboratory studies and models performed to better understand the effects of microplastics such as equilibrium partitioning, decomposition and disintegration, bioaccumulation, and implications and risks of chemicals [5]. However, most studies that are performed in the field which are mainly observational.

Microplastics can be categorized in two parts: primary the feedstock pellets used in the plastic industry or secondary the breakdown of larger plastic pieces [6]. Here are a few reasons why microplastics could be harmful: according to the United Nations Globally Harmonized System (GHS) more than 50\% of the plastics are a part of hazardous monomers, additives, and chemical byproducts [4], the additives in plastic can leach out of the ingested plastic [7], and persistent organic pollutants (POPs) can absorb the plastic fragments which can clean the water of the pollutants, but it can be a source of toxicity to the organisms that ingest the particles [7].

Many species around the world are affected by plastics by either entanglement or ingestion. Entanglement is a more visual, external issues for marine life with larger plastic particles, while ingestion is not as visual, but rather an internal issue and usually deals with smaller plastic particles [8]. A study performed in 1997 by Laist [9], shows 177 species were affected by the ingestion of microplastics. A similar study was performed by Kuhn in 2015 and shows 331 species [8] were affected by microplastic ingestion.

Ingestion could be broken down into two parts: intentional (foraging, color, age) or accidental/secondary ingestion [8]. Foraging is common a common way of microplastic ingestion in seabirds due to how they feed, it can be passed through their stomachs or regurgitated since they are used to doing that with other prey remains [8]. Color of the plastic and age of the species are other factors of intentional ingestion. Species are attracted to specific colors that are of their prey [8]. Age is a factor since younger species usually ingest more plastic than older ones [8].

Accidental ingestion and secondary ingestion are other components that affect marine life. Accidental ingestion is common with species which filter larger bodies of water into their systems while eating. On the other hand, secondary ingestion is when a species consume prey which has ingested plastic. The impacts of ingestion vary from mortality, indirect physical effects, chemical effects, chain effects, and species dispersal [8]. Death can occur if the gastrointestinal tract is blocked or damaged when the plastic is ingested, while the indirect physical effects can be blockage or damage of the digestion tract impacting poor nutrition and dehydration in animals, reduced stomach storage, ulcerations, and interference with brain signals [8]. Chemical effects can occur from the breakdown of plastics. The chemicals released from the additives in the plastic break down during the digestive processes and the chemicals can be released. Chain of impacts of plastic ingestion are common in seabirds (due to breeding seasons and winter travel) and can be bio-transferred to different environment [9].

The purpose of this study is to compare microplastic ingestion of seabird species to other marine species globally. Other marine species include: sea turtles, fish, marine mammals, and invertebrates.

\section{Methodology}

In order to compare if seabirds have more microplastic ingestion than other marine species globally, a literature review was done on microplastics and its effects on marine species. The majority of studies are qualitative, focusing on documenting the effects rather that comparing which species is more affected. One review study was found with data from different studies [10]. From this study, a computation was done by continent or ocean on the population of different species affected in order to find out whether seabirds are more prone to impacts from microplastics. The number of species were counted based on continent and ocean, and the total studied were summed. In order to find the number of seabirds or other marine species with microplastic ingestion, the average percentage of species with microplastic ingestion was converted to a percent and then multiplied by the total studied. Since species can only exist fully, the decimal value was rounded up if applicable in both the average percentage of microplastics ingested and the number of plastic ingestions.

For visual representation, a bar graph comparing the average percentage of ingested plastic of seabird species to the other marine species in the common locations. Two additional bar graphs were created to show all the continents and oceans of the average percent of ingested microplastic for the seabirds and other marine organisms.

\section{Results}

The data on seabird species from Lusher (2015) were analyzed and computations were done. Table 1 and figure 1 present the seabird population affected by microplastic ingestion by continent, while table 2 and figure 2 show the same information for other marine species.

Table 1. Seabird species affected by microplastic ingestion $\mathrm{d}$ by continent

\begin{tabular}{|c|c|c|c|c|}
\hline $\begin{array}{c}\text { Location } \\
\text { (Continent/ } \\
\text { Ocean) }\end{array}$ & $\begin{array}{c}\text { Average \% of } \\
\text { Microplastic } \\
\text { Ingestion }\end{array}$ & $\begin{array}{c}\text { Number } \\
\text { of Species }\end{array}$ & $\begin{array}{c}\text { Total } \\
\text { Studied }\end{array}$ & $\begin{array}{c}\text { Number of } \\
\text { Seabird } \\
\text { Species } \\
\text { with Plastic } \\
\text { Ingestion }\end{array}$ \\
\hline Antarctica & 24 & 10 & 1036 & 250 \\
\hline
\end{tabular}

\section{RIC}


Baran (et al): Microplastic ingestion: Are seabirds more affected than other marine species?

\begin{tabular}{|c|c|c|c|c|}
\hline Arctic Ocean & 24 & 2 & 201 & 47 \\
\hline $\begin{array}{c}\text { Atlantic } \\
\text { Ocean }\end{array}$ & 47 & 13 & 1556 & 735 \\
\hline Australia & 58 & 3 & 195 & 114 \\
\hline Europe & 51 & 10 & 267 & 137 \\
\hline $\begin{array}{c}\text { North } \\
\text { America }\end{array}$ & 57 & 44 & 3588 & 2057 \\
\hline Oceania & 37 & 7 & 1318 & 485 \\
\hline $\begin{array}{c}\text { Pacific } \\
\text { Ocean }\end{array}$ & 60 & 30 & 2446 & 1472 \\
\hline $\begin{array}{c}\text { South } \\
\text { America }\end{array}$ & 78 & 9 & 128 & 100 \\
\hline $\begin{array}{c}\text { Southern } \\
\text { Ocean }\end{array}$ & 43 & 29 & 3141 & 1348 \\
\hline
\end{tabular}

Source: Data from 10.

Table 2. Marine species (except seabirds) affected by microplastic ingestion, by continent and ocean

\begin{tabular}{|c|c|c|c|c|}
\hline $\begin{array}{c}\text { Location } \\
\text { (Continent/ } \\
\text { Ocean) }\end{array}$ & $\begin{array}{c}\text { Average \% } \\
\text { of } \\
\text { Microplastic } \\
\text { Ingestion }\end{array}$ & $\begin{array}{c}\text { Number } \\
\text { of Species }\end{array}$ & $\begin{array}{c}\text { Number of } \\
\text { other } \\
\text { Total } \\
\text { Studied }\end{array}$ & $\begin{array}{c}\text { Species with } \\
\text { Plastic } \\
\text { Ingestion }\end{array}$ \\
\hline Asia & 38 & 1 & 16 & 6 \\
\hline $\begin{array}{c}\text { Atlantic } \\
\text { Ocean }\end{array}$ & 6 & 6 & 959 & 54 \\
\hline Australia & 100 & 1 & 146 & 146 \\
\hline Europe & 43 & 18 & 2330 & 994 \\
\hline $\begin{array}{c}\text { North } \\
\text { America }\end{array}$ & 34 & 10 & 204 & 68 \\
\hline $\begin{array}{c}\text { Pacific } \\
\text { Ocean }\end{array}$ & 29 & 21 & 1532 & 442 \\
\hline $\begin{array}{c}\text { South } \\
\text { America }\end{array}$ & 15 & 9 & 1201 & 183 \\
\hline
\end{tabular}

Source: Data from 10.

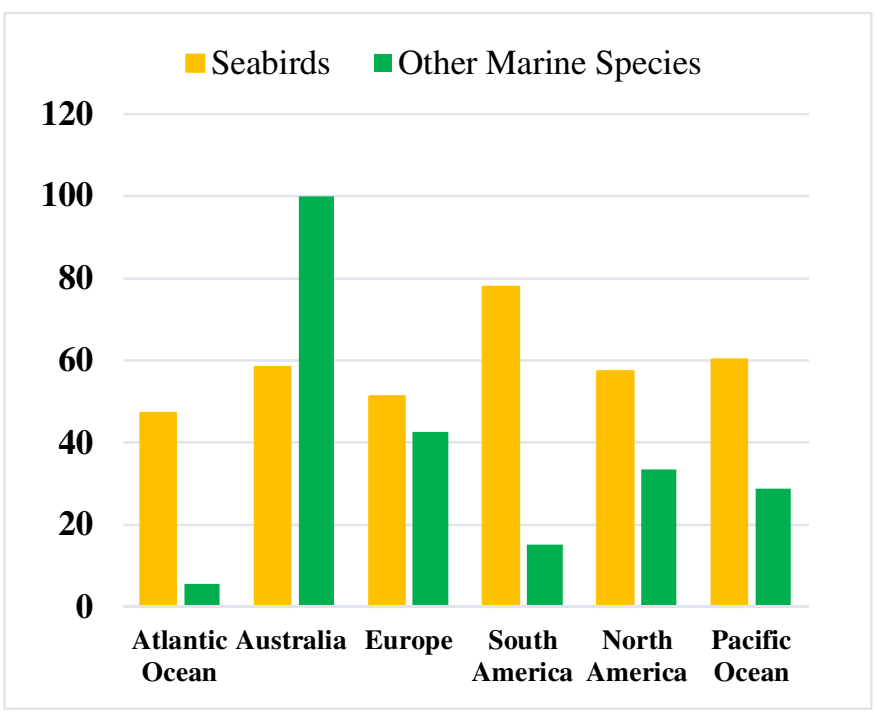

Figure 1. Comparison of seabirds to other marine species average percentage of plastic ingestion.

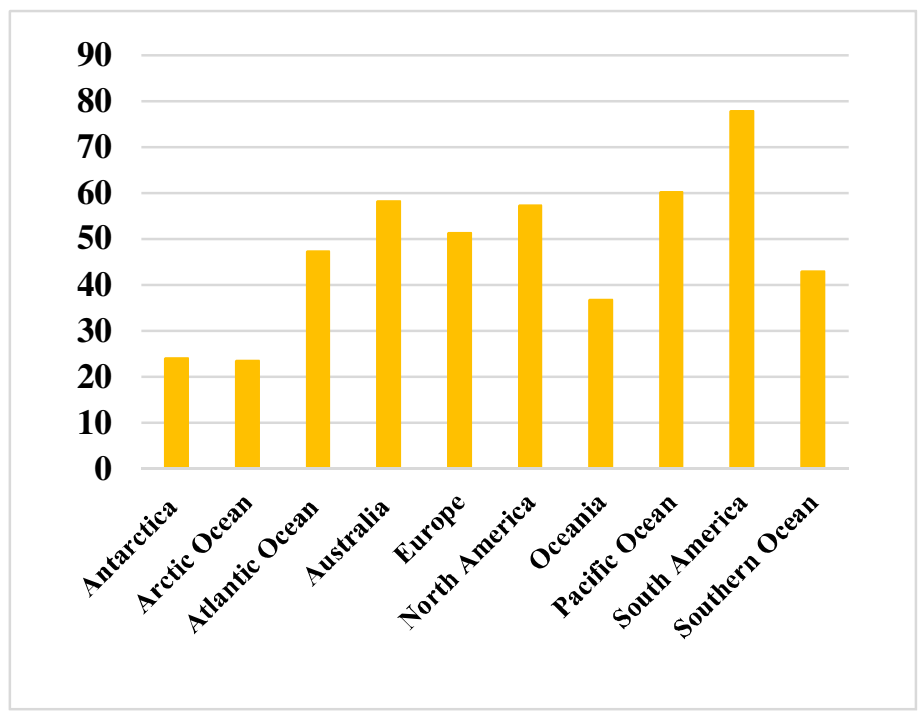

Figure 2. Seabird species average percentage of microplastic ingested for all continents and oceans.

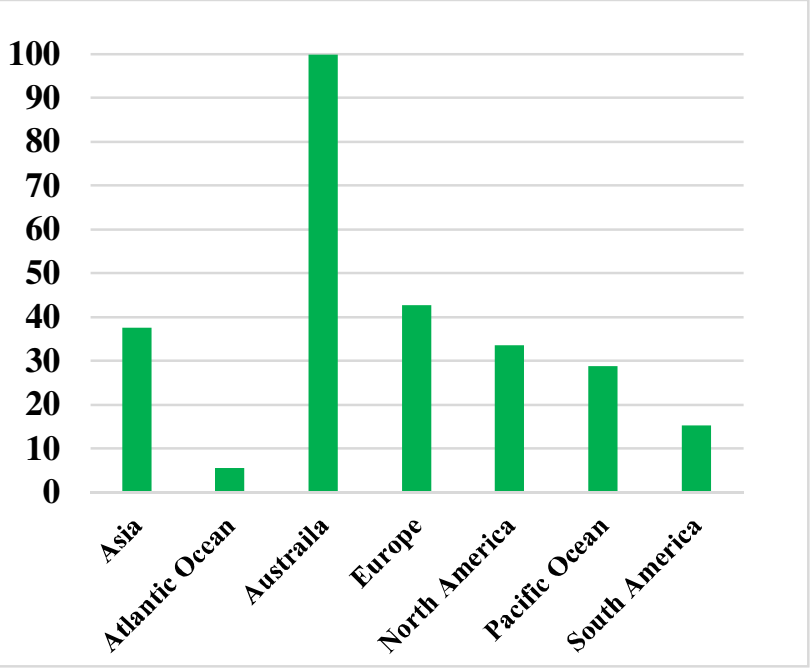

Figure 3. Other marine species average percentage of microplastic ingested for all continents and oceans.

The common continents and oceans between the seabirds and other marine species were the Atlantic Ocean, Australia, Europe, North America, and the Pacific Ocean. From figure 1, all but one location had higher percentage of microplastic ingestion in seabirds than other marine species. The country that did share the trend was Australia, other marine species had a higher percentage $(100 \%)$ of microplastic ingestion while seabirds were 58\%. The Atlantic Ocean had about $47 \%$ of seabirds with microplastic ingestion while other marine species were only about $6 \%$. Europe's average microplastic ingestion of seabirds was about $51 \%$ and other marine species were $43 \%$. South America had an average of microplastic ingestion in seabirds of $78 \%$ and other marine species, $15 \%$. North America 
had an average of $57 \%$ for seabirds and $34 \%$ for other marine species. The Pacific Ocean had $60 \%$ of microplastic ingestion in seabirds and $29 \%$ for other marine species.

For seabirds, the other continents and oceans included Antarctica, Artic Ocean, and Oceania (10 locations total). The average percentage of microplastic ingestion in seabirds from these locations were: Antarctica (24\%), Artic Ocean (24\%), and Oceania (37\%).

For other marine species, the additional location included Asia (7 locations total) which had an average of microplastic ingestion of $38 \%$. Seabirds are the most common species to be attracted to microplastic ingestion.

\section{Discussion}

Out of the common locations of both seabird species and other marine species, Australia was the only location which other marine organisms had a higher average percentage of microplastic ingestion than seabird species. The reasoning could be the other marine species only had one species contribute to the results, 1 fur seal with 146 scats, feces contributing to $100 \%$ microplastic ingestion.

Another interesting result from the data was the South America seabird species and other marine species. While it did follow the trend of seabird species ingesting more plastic than other marine species, the number of other marine organisms studied was 1201 , while the seabirds were only 128 but still had a larger percentage of microplastic ingestion and the same number of species studied.

From the results, seabird species are more affected by microplastic ingestion than other marine species. This could be due to the fact there is more seabird species data than other marine species. Seabirds are located around the world so it is an easier species to analyze. Seabirds also hunt prey by foraging. This way of consuming food can increase plastic ingestion due to plastic's buyoance.

\section{Conclusions}

Due to anthropogenic use of plastic, the effects on marine life when it becomes debris is becoming a rising issue and concern. As the plastic breaks down and filters into the marine environment, many species are being observed to see how the microplastics are affecting them. From a global stand point and the average percentage of microplastic ingestion, seabird species are more prone to ingestion microplastics than other marine species in common locations of previous studies (Altantic Ocean, Europe, South America, North America, and the Pacific Ocean).

\section{ACKNOWLEDGMENT}

I would like to thank the $100-\mathrm{K}$ Strong in the Americas Grant and Wilkes University for the opportunity to do an exchange program at Universidad Technologica de Panama. I would also like to thank Universidad Technologica de Panama for the experience to take a research methods course. In addition, to the universities, special thanks go to Dr. Murhty and Dr. Casilda Saavedra for the support while writing this article.

\section{REFERENCES}

[1] J. G. B. Derraik, "The pollution of the marine environment by plastic debris: a review," Mar. Pollut. Bull., vol. 44, no. 9, pp. 842-852, 2002.

[2] D. W. Laist, "Impacts of marine debris: entanglement of marine life in marine debris including a comprehensive list of species with entanglement and ingestion records," in Marine Debris, Springer, 1997, pp. 99-139.

[3] M. Eriksen et al., "Plastic pollution in the world's oceans: more than 5 trillion plastic pieces weighing over 250,000 tons afloat at sea," PLoS One, vol. 9, no. 12, p. e111913, 2014.

[4] C. M. Rochman, E. Hoh, T. Kurobe, and S. J. Teh, "Ingested plastic transfers hazardous chemicals to fish and induces hepatic stress," Sci. Rep., vol. 3, p. 3263, 2013.

[5] A. A. Koelmans, "Modeling the role of microplastics in bioaccumulation of organic chemicals to marine aquatic organisms. A critical review," in Marine anthropogenic litter, Springer, Cham, 2015, pp. 309-324.

[6] F. Faure, M. Corbaz, H. Baecher, V. Neuhaus, and L. de Alencastro, "Pollution due to Plastics and Microplastics in Lake Geneva," in 6th International conference on water resources and environmental research, 2013, no. EPFL-POSTER-187023.

[7] A. L. Andrady, "Microplastics in the marine environment," Mar. Pollut. Bull., vol. 62, no. 8, pp. 1596-1605, 2011.

[8] S. Kühn, E. L. B. Rebolledo, and J. A. van Franeker, "Deleterious effects of litter on marine life," in Marine anthropogenic litter, Springer, Cham, 2015, pp. 75-116.

[9] S. C. Gall and R. C. Thompson, "The impact of debris on marine life,” Mar. Pollut. Bull., vol. 92, no. 1-2, pp. 170-179, 2015.

[10] A. Lusher, "Microplastics in the marine environment: distribution, interactions and effects," in Marine anthropogenic litter, Springer, Cham, 2015, pp. 245-307. 